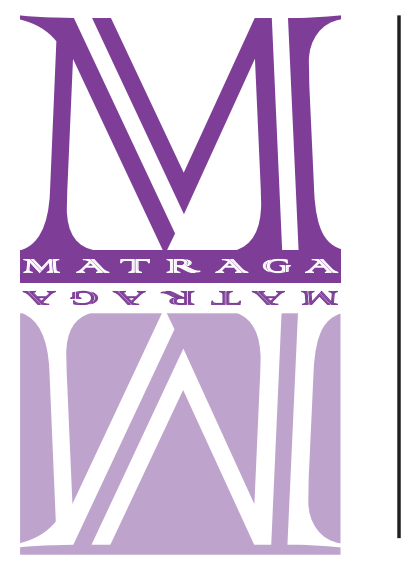

\title{
Marques de Carvalho (1866-1910) e o Naturalismo na Amazônia paraense
}

\author{
Alan Victor Flor da Silva \\ Colégio Militar de Belém (CMBEL), Brasil \\ https://orcid.org/0000-0003-4666-9888
}

\begin{abstract}
RESUMO
João Marques de Carvalho (1866-1910) foi um dos poucos escritores a conseguir na Amazônia paraense publicar uma produção literária tanto em periódicos quanto em volumes, a exemplo de poemas, contos e romances. Em prefácios de livros e publicações periódicas de naturezas diversas, o escritor paraense levantou com entusiasmo e veemência a bandeira do Naturalismo, estilo literário considerado excessivamente realista e cru, que adotou, defendeu e cultivou ao longo da carreira. Dessa maneira, Marques de Carvalho colocouse na contracorrente da produção literária cultivada na província do Pará, pois a maioria dos colegas de ofício radicados na Belém oitocentista se demonstrava mais afeita ao Romantismo. Diante disso, objetivamos demonstrar como Marques de Carvalho se posicionou em relação ao Naturalismo e estudar as principais contribuições do autor paraense a esse estilo literário na Amazônia paraense, a partir dos romances O pajé (1887) e Hortência (1888), ambos publicados e ambientados em Belém do Pará.
\end{abstract}

PALAVRAS-CHAVE: Marques de Carvalho; Naturalismo; Amazônia.

\section{Marques de Carvalho (1866-1910) and Naturalism in the Pará Amazon}

\begin{abstract}
João Marques de Carvalho (1886-1910) was one of a few writers that managed to publish a great literary production, as periodics and as volumes, for example poems, short stories, or novels, in the Amazon, in the state of Pará. In prefaces of books and periodic publications, the author raised, with enthusiasm and vehemence, the flag of Naturalism, literary style considered excessively realistic and raw, that he adopted, protected, and devoted along his career. This way, Marques de Carvalho put himself against the literary production practiced in Pará, because most of his coworkers in Belém at the nineteenth century showed much affection to the Romantism, which was still quite expressive in Brazil, even with the appearance of new literary tendencies in the last two decades of the nineteenth century. Therefore, we aim with this paper to demonstrate how Marques de Carvalho positioned himself in relation to Naturalism and to study the main contributions of the author from Pará to this literary style in the Pará Amazon, from the novels O pajé (1887) and Hortência (1888), both published and set in Belém do Pará.
\end{abstract}

KEYWORDS: Marques de Carvalho; Naturalism; Amazon. 


\section{Introdução}

Herculano Marcos Inglês de Sousa (1853-1918), José Veríssimo Dias de Matos (1857-1916) e João Marques de Carvalho (1866-1910) foram escritores oitocentistas nascidos na província do Pará que receberam algum destaque nas histórias literárias canônicas, sendo todos vinculados ao movimento naturalista. Contudo, enquanto Inglês de Sousa e José Veríssimo saíram da região amazônica para obter projeção no campo literário em outras partes do território nacional, sobretudo no Rio de Janeiro, capital do país na época, Marques de Carvalho se distingue por ter tentado construir uma carreira de jornalista e escritor na cidade de Belém do Pará.

Tradicionalmente vinculado ao naturalismo e à literatura científica pelas histórias literárias, Marques de Carvalho aparece junto a outros representantes considerados "menores" do movimento naturalista no Brasil. Apesar de discreta, a presença do autor nos manuais escolares se deve a um "fenômeno literário" ocorrido em 1888, quando foram publicados três romances supostamente inspirados pelo best-seller naturalista $O$ homem, de Aluísio Azevedo, lançado nos últimos meses do ano anterior (SILVA; SALES, 2019b): A carne, de Júlio Ribeiro; O cromo, de Horário de Carvalho; e Hortência, principal obra de Marques de Carvalho, que narra uma história de incesto ambientada em Belém do Pará.

Apesar de ter pouco espaço nas histórias literárias canônicas, Marques de Carvalho foi uma celebridade na capital paraense. Periódicos que circulavam pela Belém oitocentista veiculavam com frequência seu nome, mesmo em se tratando de notícias banais, relacionadas à sua vida pessoal, como viagens, doenças e participações em eventos diversos. Sempre comprometido com o combate ao marasmo do cenário literário na capital paraense, o escritor lutou com garra pela causa das letras na Belém oitocentista, engajando-se na criação de periódicos e agremiações, como a Mina Literária (1894), e a Academia Paraense de Letras (1900), a fim de incentivar e promover a produção literária de escritores radicados na província do Pará.

Em distintas publicações periódicas, Marques de Carvalho demonstrou preocupação com o presente e o futuro da literatura produzida na Amazônia paraense. Em 1887 criou A Arena, um periódico artístico e literário, no intuito de estimular e divulgar poemas e contos produzidos por autores enraizados em Belém. Sempre procurou exaltar o talento dos colegas de ofício com quem mantinha laços de amizade, como Carlos Hipólito de Santa Helena Magno (18481882), Teodorico Francisco de Assis Magno (1866-1885) e Paulino de Almeida Brito (18581919). Esses autores foram cruciais para a constituição de um grupo de escritores na Belém do final do século XIX, a fim de impulsionar uma produção literária na Amazônia paraense que pudesse ser chamada de "literatura paraense", "literatura amazônica" ou "literatura do norte" (SILVA; SALES, 2019a).

Neste artigo, demonstraremos como Marques de Carvalho se posicionou em relação ao Naturalismo, assim como também estudaremos as principais contribuições do escritor à "literatura do real" na Amazônia paraense, a partir dos estudos dos romances O pajé (1887) e Hortência (1888), ambos publicados e ambientados em Belém do Pará. Dividido em três seções, será abordado, na primeira parte deste estudo, como Marques de Carvalho, quando ainda era um jovem escritor, foi favorável ao Romantismo e avesso ao Naturalismo; na segunda e terceira partes, 
serão analisados, respectivamente, os romances O pajé e Hortência, a fim de compreender a maneira como o escritor paraense, à luz do estilo literário ao qual se vinculara, idealizou essas obras literárias.

\section{Marques de Carvalho e Paulino de Brito, antirrealistas}

A carreira de Marques de Carvalho como jornalista e homem de letras em Belém do Pará teve início no dia 2 de setembro de 1883. Naquela data, aos 16 anos de idade, o jovem escritor estreou no mundo literário com a publicação do poema romântico "Confissão" nas páginas do Diário de Belém. Como ele, outros escritores naturalistas estrearam na literatura com poesia romântica, tal qual Adolfo Caminha (1867-1897), que publicou o livro de poemas lacrimejantes Voos incertos (1886). A partir desse poema inaugural, o jovem Marques de Carvalho se posiciona contra o Realismo e a favor do Romantismo, cujos princípios são verificáveis em outros trabalhos produzidos por ele e divulgados em periódicos da capital paraense durante os primeiros anos da década de 1880 .

O posicionamento antirrealista do jovem Marques de Carvalho fica evidente na relação de apoio mútuo que tinha com Paulino de Brito. Apesar de pouco conhecido fora do Pará, Paulino de Brito foi outro escritor amazonense radicado em Belém que em pouco tempo conseguiu uma posição de relevo no cenário literário da capital paraense do final do século XIX. No soneto "Resolução", dedicado a ele e publicado no dia 18 de janeiro de 1885 na coluna "A pedidos" do Diário de Belém, um nostálgico Marques de Carvalho lamenta o fato de os poetas, seduzidos pelo "gozo bestial" oferecido pela voga realista do segundo oitocentos, não mais se dedicarem à produção de versos "meigos e inocentes", romanticamente idealizados. No início da carreira, Marques de Carvalho rejeitava o excesso de realismo das produções naturalistas, consideradas vulgares e obscenas. Nesse momento, o Naturalismo não passava de uma "asneira":

\footnotetext{
Poeta, escuta: o tempo é bom pra o egoísmo,

pra prova sensabor, pra o gozo bestial;

agora só se encontra o pedantismo

de braço com a impudência cínica, imoral.
}

\footnotetext{
Esfrega-se na lama o célico lirismo

da Musa do presente, - a Musa sensual,

que se ocupa de dia em mantos de ascetismo

e à noite vai dançar na imunda bacanal.
}

Não vale ser poeta meigo e sorridente,

Cantar a virgindade cândida, inocente

Nuns versos ideais, à margem da ribeira...

Por isso eu já mandei a minha pobre Musa

tomar um banho bom à fonte de Aretusa,

e fico aqui, sozinho, olhando a tanta asneira. (Diário de Belém, 18 jan. 1885, p. 3.) 
Dias depois da publicação do poema, Marques de Carvalho outra vez elogiou Paulino de Brito pelo vínculo com o Romantismo e repúdio ao Realismo. Em fevereiro de 1885 publicou no Diário de Belém um artigo dividido em quatro partes com considerações sobre a vida e a produção literária do amigo e colega de ofício. No fascículo do dia 25 de fevereiro, Marques de Carvalho faz uma apreciação crítica de $O$ homem das serenatas, o primeiro romance de Paulino de Brito, publicado em folhetins no Diário de Belém de 1 de janeiro a 5 de março de 1882 . O trabalho é elogiado por ser "ornado de boa moral" e por ter como base a escola romântica: "[n] o Homem das Serenatas, Paulino de Brito filiou-se a essa escola sentimental, que se dedica a estudar, a analisar as chagas do coração humano [...] Tarefa espinhosa, árdua, difícil, - essa, - e que muitas vezes envia as lágrimas aos olhos de quem nela se ocupa" (Diário de Belém, 18 jan. 1885 , p. 2).

A escolha dos verbos "estudar" e "analisar" não é aleatória, pois são palavras-chave da "literatura do real" do século XIX, do empenho de representar a realidade "como ela é", de modo "científico", como vemos na literatura naturalista. Na França, o próprio Zola considerou substituir a palavra "romance" pela palavra "estudo" para melhor descrever a literatura de observação e análise que os naturalistas faziam (ZOLA, 1995). Ao dizer que a literatura romântica "estudava" "as chagas do coração humano", Marques de Carvalho sugere que ela também era "realista" a seu modo e que, portanto, estava à altura das exigências de verdade e de realidade do fim do século. Acrescenta que fazer literatura romântica era tarefa tão exigente e "árdua" quanto fazer realismo.

Após elogiar Paulino de Brito pela criação de O homem das serenatas, Marques de Carvalho condena, justamente pela ausência de moralidade, os romances produzidos pelos adeptos da "moderna escola realista", e dá como exemplo obras naturalistas francesas e portuguesas, como Pot-Bouille (1883), de Émile Zola e o anticlerical O crime do padre Amaro (1875), de Eça de Queiroz (1845-1900), assim como o "romance de sensação" Mademoiselle Giraud, ma femme (1877), de Adolphe Belot (1829-1890). Como outros detratores do Naturalismo do período, Marques de Carvalho era da opinião de que essas obras faziam mal aos leitores e contribuíam para a decadência da sociedade: "Os frutos dela [moderna escola realista] produzem indigestões dolorosas no estômago de quem as ingere. [...] E queixam-se da desmoralização da sociedade!..." (Diário de Belém, 18 jan. 1885, p. 2).

\section{A virada realista: 0 pajé (1887)}

A partir de 1887, em prefácios de romances e publicações periódicas, Marques de Carvalho se afasta do Romantismo e começa a levantar com entusiasmo a bandeira da "literatura do real" e do Naturalismo, estética que adotou, passou a defender e a que ficou associado na posteridade. Nessa época, o escritor, aos vinte anos de idade, deixa de ser um detrator para se tornar um defensor do novo estilo literário. Sua vinculação ao Naturalismo, porém, foi marcada por uma tensão constante. $\mathrm{O}$ autor precisou negociar os conflitos próprios do campo literário paraense, ainda em formação, advogando pela "literatura científica" e, ao mesmo 
tempo, ajudando a constituir e dar visibilidade, por meio de publicações em periódicos da Belém oitocentista, a uma plêiade de escritores na província do Pará que ainda eram vinculados ao Romantismo.

Em 18 de janeiro de 1887, Marques de Carvalho lançou O pajé em fatias seriadas no rodapé de A República. O título vinha acompanhado do epíteto: "romance naturalista". No prefácio, o autor anuncia que se orgulhava de ser o primeiro escritor radicado na província do Pará a lançar um romance naturalista: "É O pajé o primeiro trabalho de seu gênero escrito por um paraense: cabe-me essa glória, tenho a máxima honra em reclamá-la”. Em seguida, declara ter cortado definitivamente os laços que o mantinham atados aos ideais românticos: "alienei-me da velha escola romântica, desprezei-lhe os abusos e prolixidades, para deixar-me levar pela grande orientação literária da nossa época”. Por fim, o autor prevê que seu romance, pela "rudeza de suas cenas copiadas da vida real", não seria bem recebido pelos "conservadores românticos":

\footnotetext{
Bem sei que este livro causará escândalo na família paraense, pela rudeza de suas cenas copiadas da vida real com o maior e mais consciencioso escrúpulo. Tenho quase que uma certeza dos ataques violentos que vão ser dirigidos pelos conservadores românticos, dos quais a renitência em permanecerem na olvidada escola é deveras contristadora. Mas eu não acovardo, não volto atrás: espero que a justiça me será feita um dia, quando a evolução, beneficamente fatal, houver curvado todas as cabeças à moderna fórmula literária. Aqueles que pateiam hoje o realismo, aplaudi-lo-ão amanhã, logo que o tenham compreendido (A República, 18 jan. 1887, p. 3.).
}

Além da preocupação com a possível resistência dos leitores à publicação de uma obra realista que, como tal, fazia a exposição de cenas "rudes" em desacordo com a moral vigente na época, o prefácio de $O$ Pajé pode ser compreendido como uma forma de propaganda para atrair compradores de jornal e despertar o interesse dos leitores por uma narrativa ficcional disponibilizada em fascículos seriados. Nesse sentido, Marques de Carvalho, quando alega ter escrito um romance que causaria escândalo na família paraense, despertava a curiosidade dos leitores belenenses da época, que sentiriam o desejo de comprar o jornal para ler uma narrativa ficcional rude e realista, com a promessa de um enredo permeado de episódios picantes e proibidos.

O mesmo recurso publicitário de incitação pela promessa de sexo foi utilizado por outro escritor naturalista brasileiro. Naquele mesmo ano de 1887, quando publicou o romance $O$ homem, que seria o precursor de Hortência, Aluísio Azevedo colocou na folha de rosto uma polêmica advertência: "Quem não amar a verdade na arte e não tiver a respeito do Naturalismo ideias claras e seguras, fará, deixando de ler esse livro, um grande obséquio a quem o escreveu" (AZEVEDO, 2003, p. 7). Segundo Leonardo Mendes e Cleyciara Garcia Camello (2019, p. 68), ao pedir ao leitor para não abrir o livro se não soubesse o que era o Naturalismo, Aluísio conseguia justamente o efeito oposto. Assim, a "advertência funcionava como um convite de leitura". Com base nisso, podemos supor que Marques de Carvalho teria a mesma percepção.

Apesar de fazer reclame com a advertência de escândalo, foram encontradas poucas críticas a O pajé na imprensa periódica paraense. No dia 20 de fevereiro de 1887, saiu no jornal Diário de 
Notícias um artigo intitulado "Pela literatura...", assinado por Mefistófeles, pseudônimo de Luiz Demétrio Juvenal Tavares (1850-1907), homem de letras e jornalista paraense. O autor congratula os jovens comprovincianos que estavam lançando romances nas páginas de periódicos paraenses. Nesse período, Paulino de Brito publicava Dolores no Diário do Grão-Pará; Pontes de Carvalho trazia à luz Maria Clara em A Província do Pará; e Marques de Carvalho, por fim, divulgava $O$ pajé em A República. Mefistófeles recomenda a leitura do romance, tendo como referência mais o peso do nome do autor do que a qualidade da narrativa ficcional: "A República vai desenrolando o Pajé do sr. Marques de Carvalho, romance que parece fundar-se em costumes paraenses. Não posso antecipar o juízo sobre esta criação do sr. Carvalho, cujo nome já é uma irrecusável garantia de sucesso" (Diário de Notícias, 20 fev. 1887, p. 2).

O romance expõe o drama de uma família abastada de Belém que, mesmo recorrendo a médicos e medicamentos, não consegue encontrar a cura para a enfermidade da única filha, Generosa, vítima de tuberculose. Assistindo ao agravamento do estado de saúde da menina e com o intuito de restabelecê-la sem poupar esforços, os pais - Mathias de Almeida e d. Josefa - recorrerem aos cuidados de um pajé chamado Pedro. No prefácio, Marques de Carvalho descreve a figura como um "personagem astucioso e hipócrita que é o terror dos espíritos fanáticos do povo de minha província”. Durante o século XIX, muitos periódicos paraenses noticiavam casos de pajelança na província do Pará. Tal fato demonstra como essa prática era comum nessa época na Amazônia, sugerindo que o escritor paraense, inspirado pelo cientificismo da época, construiu um romance para representar não apenas a figura polêmica de um pajé em meio a uma sociedade em processo de modernização graças ao boom do comércio da borracha, como também o embate entre a ciência e o curandeirismo no final do século XIX (BARBOSA, 2011).

Além do pajé, outra figura simbólica da Belém oitocentista que aparece no romance é a parteira negra, representada por tia Faustina. Enquanto o pajé, como podemos inferir a partir do prefácio do romance, seria um charlatão, tia Faustina, responsável pelo parto de Generosa, era uma pessoa querida pelos membros da família da protagonista, de tal modo que passa a frequentar, com certa intimidade, a casa de Mathias de Almeida. No romance, a parteira faz uma mediação entre o conhecimento médico-científico e o saber popular tradicional, entre a casa burguesa e o casebre do curandeiro, e é ela quem recomenda os remédios do Pajé para tratar da doença de Generosa. Quando cria personagens como médicos, pajés e parteiras, Marques de Carvalho mostra como as práticas da medicina e do curandeirismo coexistiam na província do Pará no século XIX.

Tia Faustina foi uma pessoa real e importante da Belém oitocentista. Ao inseri-la no romance como personagem, Marques de Carvalho se empenhava no caráter "documental" da ficção naturalista, que fixava tipos reais da vida cotidiana das cidades. Tal foi a importância da parteira tia Faustina na província do Pará, que Marques de Carvalho interrompe o andamento da narrativa para homenageá-la: "Permitam-me que faça uma pequena divagação, afastando-me da marcha deste romance, para deixar imortalizado num livro meu o nome mais popular que atualmente existe na sociedade paraense" (A República, 20 fev. 1887, p. 3). É como se o documental e o jornalístico se sobrepusessem ao ficcional, que é uma característica do romance naturalista (BA- 
GULEY, 1990). Marques de Carvalho tece louvores às parteiras negras e à importância do seu labor naquela sociedade:

Imaginem os leitores se pode haver numa cidade pessoa mais credora de veneração, mais digna de estima, do que essas ignorantes pretas velhas que, com o socorro duma longa prática, ajudam à realização desse laborioso ato fisiológico pelo qual uma criança entra a fazer parte dos seres humanos que por si sós, sem o auxílio de ninguém, respiram com toda a liberdade o ar que envolve o mundo! Eis a venerável missão da tia Faustina, - missão que bem merece a recompensa duma estátua e que, todavia, só possui um pequeno altar em cada um dos devotados corações maternos que compõem a face respeitabilíssima de nossa sociedade... (A República, 20 fev. 1887, p. 3).

Além de apresentar alguns personagens que são tipos sociais característicos do cotidiano da cidade de Belém no fim do século XIX - como o pajé Pedro e a parteira tia Faustina - e outros aproveitadores típicos do romance realista-naturalista que procuraram tirar vantagem da influência e do dinheiro de Mathias de Almeida - como o médico Adalgiso e o advogado Eduardo da Anunciação -, Marques de Carvalho constrói a protagonista do romance aos moldes naturalistas. Como toda filha de famílias abastadas, Generosa era estudante de francês, tocava piano divinamente, conhecia os mais importantes artistas europeus da época e sobre aqueles de maior expressão tinha opinião formada: preferia os alemães aos italianos. Em razão da paixão pela arte, chega a sonhar com a possibilidade de morar na Europa para viver de música. Em vez de idealizar romanticamente o amor e o casamento, mantinha um ponto de vista crítico e arrojado em relação aos dois - o sentimento e a instituição -, e chega a declarar que preferia ficar solteira:

Generosa jamais sentira amor. Quando se falava em casar, ria-se muito, alegando que estava moça, e que, demais, não desejava separar-se de seu bom pai, da sua querida mamãe. Se algum amigo pretendia submetê-la a confissões, a fim de indagar se ela não amava algum rapaz, a travessa menina respondia que «não tinha tempo bastante para tolices!... » [...] Ela também não se importava: vivia feliz, à vontade, nada faltava-lhe. Para que pois casar-se, correr o risco de fazer uma má escolha, entregar-se eternamente a um homem que poderia vir a maltratá-la, a fazê-la infeliz?... Não, estava muito bem como solteira... (A República, 08 fev. 1887, p. 3).

Em O pajé, Marques de Carvalho não apenas cria uma heroína com ideias excepcionais para a época sobre o amor e o casamento, como também traz à tona a discussão sobre os efeitos da leitura de romances no público feminino. O poder e o efeito da leitura sobre a sensibilidade feminina aparecem notoriamente em Madame Bovary (1857), de Gustave Flaubert, e foram revisitados em romances naturalistas brasileiros como O homem, A carne, Lar (1888), de Pardal Mallet (1864-1894) e o escandaloso O aborto (1893), de Figueiredo Pimentel (1869-1914). Como as belenenses Generosa e Mariana de Macedo, melhores amigas desde a infância, as protagonistas (na ordem) Magdalena, Lenita, Sinhá e Maricota eram hábeis leitoras e, quando não havia ninguém por perto para incomodá-las, liam romances às escondidas:

[...] abriam cautelosamente o baú, tiravam dele qualquer romance que Mariana mandava comprar às escondidas e devoraram-lhe as páginas, entusiasmando-se pelas façanhas dos cavalheiros 
da Idade Média, ou sorrindo maliciosamente nas passagens amorosas, idílicas, que ainda não compreendiam bem, mas que apareciam-lhes vagamente envoltas numa espécie de véu espesso, que elas desejavam rasgar se pudessem... (A República, 05 fev. 1887, p. 3).

Como consequência da leitura proibida de romances, Generosa e Mariana se beijam. Tal cena audaciosa confirma a intenção de Marques de Carvalho de escandalizar a sociedade belenense, à maneira da prosa naturalista em geral, como adiantou no prefácio. Numa configuração semelhante ao romance de Marques de Carvalho, em A normalista (1893), de Adolfo Caminha (1867-1897), a protagonista Maria do Carmo beija a amiga Tereza depois de lerem juntas $O$ primo Basílio, de Eça de Queiroz. Em O pajé, as moças vão além e se abraçam, se beijam e rolam juntas sobre a cama, num flerte audacioso com o amor lésbico que só era possível num romance realista e científico. Como em Madame Bovary, a leitura era um escape da monotonia da vida das mulheres:

Depois, como se sentissem invadidas de uma tristeza, de umas sentimentalidades, em resultado daquelas páginas ardentes de paixão, abraçavam-se frenéticas, beijavam-se quase alucinadas, rolando sobre a cama que rangia, experimentando a necessidade de alguma coisa nova, transformista, na sua vida monótona de raparigas sem liberdade (A República, 05 fev. 1887, p. 3).

Apesar de não ter concluído O pajé, a partir dele a vinculação Marques de Carvalho ao Naturalismo torna-se cada vez mais incisiva. No dia 12 de junho de 1887, publicou em A Arena, periódico artístico e literário do qual era proprietário, a primeira parte de um ensaio chamado " $\mathrm{Da}$ crítica literária", no qual tece considerações negativas sobre alguns colegas de ofício radicados na província do Pará que ainda se mantinham fiéis ao velho Romantismo, exaltando o Naturalismo como um estilo promissor que se estenderia até o século XX. O Romantismo era agora uma arte do passado e o presente exigia uma nova literatura, que Marques de Carvalho chama de "escola moderna", aquela que "documenta" o homem e a realidade como eles são:

\footnotetext{
Alguns poucos já conseguiram desembaraçar-se das peias do Romantismo, seguindo, sem olhar atrás, para a escola moderna, - que, mais tarde se há de impor fatal e irresistivelmente a todos, em virtude da lei eterna da evolução; - outros, porém, - o maior número, - caminham às cegas, vivendo a vida romântica dos atletas de 1830, sem que lhes passe pela mente a lembrança de que o Naturalismo abrirá a nós, moços de hoje, as portas do século XX, com essa grande chave que se chama - a escola literária dos documentos humanos! (A Arena, 12 jun. 1887, p. 1).
}

O ensaio não passou despercebido na imprensa paraense. Um cronista de A Província do Pará, sob o pseudônimo de PLAN, estabeleceu um diálogo com o escritor paraense e encetaram um debate profícuo sobre a crítica literária na província do Pará, a constituição de uma literatura paraense, amazônica ou nortista, escolas literárias, entre outros. No dia 19 de junho de 1887, em resposta a um questionamento de PLAN, Marques de Carvalho reafirma seu posicionamento a favor do Naturalismo e da "literatura do real", como as únicas capazes de satisfazer as exigências do fim do século XIX: 
A minha inabalável admiração pela escola naturalista em literatura não é só o produto do encantamento em que vivo pelo enorme talento de Émile Zola. É também, e principalmente, porque depois de um longo e profundo inquérito sobre as passadas fases da literatura, cheguei à conviç̧ão de que o Naturalismo era, nesta época, uma fatal resultante da Evolução, e a única forma por que a literatura contemporânea poderia satisfazer as exigências do público e da crítica atuais (A Província do Pará, 19 jun. 1887, p. 1).

\title{
4. Hortência (1888)
}

Para fazer jus a tal declaração, no final de 1888, aos vinte e dois anos de idade, Marques de Carvalho publica o romance Hortência - o primeiro a representar centralmente a capital paraense na literatura brasileira (MOREIRA, 1997) e o único produzido pelo autor estampado nas páginas de um livro. Uma nota publicada na edição de 8 de dezembro de 1888 do Diário de Belém anunciou a novidade e fez o vínculo com o Realismo: "Primorosamente brochado, nitidamente impresso, é o livro do Sr. Carvalho uma obra que tem de ser bastante apreciada pelos adeptos do realismo". Em nota publicada ao final da obra, o autor confirma a opção pela "áspera verdade" do Naturalismo, estética literária da qual se prontifica a ser o "porta-bandeira na Amazônia":

\begin{abstract}
A muita gente - não hesito em dizê-lo, o meu livro, que se diz naturalista, baseado nas firmes e severas máximas literária da vencedora escola de pretendo ser o porta-bandeira na Amazônia - terá parecido o produto debilitado de um sonho polucional, a criação dum cérebro transviado, um caso incongruente, medonho e estranho, incrível pelo seu horror e exposto à contemplação do público sem o titubeio duma hesitação pudica, extreme de toda a consideração para com a jesuítica hipocrisia de nosso tempo.

Mais de um leitor haverá voltado a folha, enojado, em certas páginas onde a ação natural dos fatos logicamente deduzidos se desdobra severa, inclemente em sua verdade, na sua "áspera verdade" reputando inverossímil o meu romance, crendo a sociedade contemporânea incapaz de produzir aberrações semelhantes, casos teratológicos tão notáveis (CARVALHO, 1997, p. 188).
\end{abstract}

A nota reafirma a veracidade do romance, baseado num caso verídico ocorrido dois anos antes em Lisboa, de um irmão que matou a irmã, com quem mantinha relações sexuais, quando ela quis interromper a relação incestuosa. Marques de Carvalho faz, então, a citação parcial da notícia do crime, publicada n’A Província do Pará no dia 14 de setembro de 1886. A notícia de jornal é a prova documental que o escritor apresenta para reivindicar a veracidade do seu relato, de sua "literatura do real", por mais escabrosa que seja. Outra vez, o documental e o jornalístico se sobrepõem ao ficcional. Como outros escritores naturalistas, por seu realismo cru, Marques de Carvalho era acusado de ser um "imoral e torpe fantasiador de grandes libertinagens impossíveis", quando sua tarefa havia sido apenas "copiar algumas das negras infâmias da sociedade atual" (p. 190). A escolha do verbo é essencial: o escritor naturalista "copia" o real do tempo coevo na ficção.

O romance Hortência está cheio de pistas como essas que confirmam o compromisso da obra com o Naturalismo e a "literatura do real". Além da nota ao final, na folha de rosto, uma 
epígrafe de Stendhal, o pai do realismo moderno (AUERBACH, 1971), anuncia: "La vérité, l'âpre vérité" - "a verdade, a amarga verdade" - um lema que os naturalistas levariam às últimas consequências. Em outra epígrafe, extraída do influente crítico sergipano Sílvio Romero (18511914), aparece o conselho aos romancistas que o autor de Hortência pretendia seguir: "estudai os costumes provincianos"; "tenhamos o prazer do mundo como ele é e fujamos das afetações que nos matam". Por isso, na dedicatória a José Marques Braga, o autor oferece não uma ficção, mas "esta OBSERVAÇÃO" (caixa alta no original), ou seja, Hortência narrava um caso real que fora "observado" pelo escritor-cientista.

Logo após o lançamento em dezembro de 1888, o romance foi comentado nas páginas da imprensa periódica paraense. Entre 18 e 23 de janeiro de 1889, José Veríssimo dispôs em cinco fascículos na coluna "Folhetim" de A Província do Pará um ensaio intitulado "O romance naturalista no Brasil", no qual faz uma crítica comparativa entre três romances recém-publicados da estética: O homem, A carne e Hortência. No primeiro fascículo, Veríssimo diz sem rodeios que não gosta do romance de Marques de Carvalho, embora fosse, como paraense, unido ao autor por "laços de camaradagem literária". Apoiado em valores morais, o crítico não reconhece em Hortência uma obra de valor e lamenta que Marques de Carvalho "não recuou diante das mais torpes obscenidades, reviveu a tradição simplesmente pornográfica dos livros cujos nomes nem é decente citar" (A Província do Pará, 18 jan. 1887, p. 1).

Expondo uma perspectiva crítica comum no final do século, Veríssimo acusa o Naturalismo de flertar com a pornografia (MENDES, 2019), pois Hortência, nitidamente escrito com o intuito de escandalizar e atrair leitores, não apenas "estuda" um caso de incesto entre os irmãos belenenses Hortência e Lourenço, como também descreve cenas de sexo entre eles com detalhamento, paixão e realismo, como se pode perceber no seguinte excerto:

[...] e era uma verdadeira loucura quando, à noite, a sós no quarto da rapariga, [...] entregavam-se livremente, muito sensuais e amorosos, às intermináveis expansibilidades da sua enormíssima paixão. Havia, nessas memoráveis ocasiões, requintes apurados de vício valente, estuante, fervoroso, irritando-os até às dentadas, enternecendo-os até aos afagos mais risonhos e espiritualizados, até às lágrimas mais palpitantes das profundas comoções do gozo. Rolavam, numa fúria brutal, pelo soalho nu da peça, porejando viscoso suor morno e excitante, como as grenhas soltas, eriçadas, os lábios trêmulos na junção dos beijos férvidos, as pupilas dilatadas como se desejassem abranger dum relance todos aqueles abismos de amor que se lhes cavavam nas almas furiosas de excitação e ventura. Depois, apertadamente unidos, como procurando identificar-se em mútuos amplexos, desfalecidos, arfantes, deixavam-se ficar por muitas horas juntos, na transmissão silenciosa da potência vital, ao delicioso contato das cálidas epidermes palpitantes, beijando-se calados, fechando a meio os olhos, na suprema concentração dos transcendentes êxtases! (CARVALHO, 1997, p. 116-117)

Além de se ressentir da temática indecorosa de Hortência, Veríssimo lastima que o enredo da obra se passe "exclusivamente entre gente que não nos pode interessar, em um meio a cuja vida somos estranhos". A afirmação expõe um preconceito comum da crítica oitocentista com os personagens subalternos da ficção naturalista e os espaços em que circulam, os quais, segundo o crítico, não eram dignos de literatura. Como notou Eidorfe Moreira em estudo pioneiro 
da obra (1997, p. 14), “[...] Hortência é um romance de mulatos, parecendo que o romancista quis fazer do mulato o tipo popular mais inclinado à malandragem e às aberrações sexuais". Outros mestiços haviam protagonizado romances naturalistas, como O mulato (1881), de Aluísio Azevedo, e o mesmo autor faria da lavadeira e mulata Rita Baiana a heroína de O cortiço (1890) (MENDES, 2003).

O romance de Marques de Carvalho é protagonizado por uma família de mulatos humildes e constituído por personagens de classes sociais marginalizadas da sociedade belenense da época, como lavadeiras, prostitutas, vendedoras de açaí, sapateiros, aguadeiros e homens vadios. Embora tais características desagradassem a José Veríssimo, Hortência, como obra naturalista, dava representação literária a grupos socialmente marginalizados, como os marinheiros de Bom-Crioulo (1895), de Adolfo Caminha, e as lavadeiras e os cavouqueiros de O cortiço (MENDES, 2008).

Como obra naturalista e científica, Hortência conforma os personagens às crenças do determinismo biológico, da hereditariedade e das misturas de raças (SIMÕES JUNIOR, 2014), assim como os vê como organismos suscetíveis às influências do meio paraense. Ao contrário da irmã, que "trabalha[va] valentemente com a mãe, lavando roupa, com os fortes braços metidos na barreta" e "crescera sempre naquele meio operoso e adquirira na convivência com a mãe um intenso amor ao trabalho" (CARVALHO, 1997, p. 40-41), Lourenço "era um vadio consumado, um desses gênios essencialmente paraenses, - voluptuoso, amigo da boa vida, dos dias inteiros passados na rede, abraçado à viola, tocando melopeias fáceis acompanhadas pela monotonia do ranger dos esses nos ganchos das paredes" (CARVALHO, 1997, p. 39).

Para mostrar que tais características eram inerentes à personalidade de Lourenço (ou seja, corriam no seu sangue, literalmente), o narrador destaca os esforços inúteis da mãe para mudá-lo: "nunca pudera fazer dele um homem de bem. Os seus instintos prevaleciam sempre, mau grado os atuais conselhos da velha e as antigas surras com galho de cuieira, quando Lourenço era rapaz endiabrado e revelava perversidades negras, cheias de requintes maldosos" (CARVALHO, 1997, p. 39-40). Assim, o grande apetite sexual do mulato, também apresentado como traço intrínseco à constituição do personagem, é enfatizado muitas vezes no romance. O capítulo V, por exemplo, descreve o estado de excitação do rapaz depois de assistir à apresentação de uma ginasta no circo que havia chegado a Belém. O narrador naturalista normaliza a experiência, que é tão automática como o cio dos animais e própria de um "mulato saudável" e "robusto" como Lourenço:

\footnotetext{
Havia meia-hora que se recolhera e não pudera ainda adormecer. Voltava-se a cada instante na rede, a ruminar secretas ideias de gozo e felicidade junto a uma robusta ginasta que vira no circo, vestida de maillot róseo lantejoulado, ostentando as fartas linhas da sua opulência plástica. Um fogo ardentíssimo corria-lhe pelo sangue, queimava-lhe as orelhas, dava-lhe tremuras aos dedos crispados sobre a epiderme palpitante ao peito. Estirava as pernas ao longo da rede, numa volúpia extrema dos seus fantasiosos sentidos de mulato saudável. [...] Estava como um animal no cio: trêmulo, nervoso, arfante, ardendo em febre. [...] Os pelos do corpo levantavam-se-lhe com os calafrios que percorriam-lhe os membros. Cãimbras ensaiavam-se nos pés e nas pernas do robusto rapaz. Era um esbandalhamento geral do sistema nervoso à força da veemente excitação do espírito (CARVALHO, 1997, p. 78-79).
} 
Esse traço inerente à constituição psíquica e física de Lourenço o leva, por fim, a desejar a irmã: "Ideava formosamente apetitoso o corpo de Hortência e começou a experimentar vagos desejos de vê-la, de sentir-lhe o calor do sangue de encontro ao seu corpo, de afagá-lo carinhosamente, longamente [...]" (CARVALHO, 1997, p. 79). A moça é incapaz de resistir e acaba aceitando a situação como "obra do destino" (MOREIRA, 1997, p. 15), embora também amasse o irmão, lhe exigisse luxos como se fosse sua esposa, e às vezes até o seduzisse, como na cena em que, para apaziguá-lo, exibe "as rijas modelações das suas opulentas carnes, puxando-o para si, frenética e cheia de ronronante sensualidade, como se pretendesse eliminá-lo do mundo, escondendo-o dentro de si própria, fazendo-o viver da sua vida eternamente, protetoramente" (CARVALHO, 1997, p. 119).

Por fim, o desfecho trágico do romance de Marques de Carvalho se dá aos moldes naturalistas. Como Hortência, O cortiço e Bom-Crioulo terminam com mortes trágicas e violentas. Se na tragédia clássica o destino do herói era traçado pelos deuses, na tragédia naturalista ele está escrito no corpo do personagem (BAGULEY, 1990). Naturalmente propenso ao excesso e ao crime, Lourenço ainda sofre as influências do Pará malandro e vadio. Ele aparece alcoolizado no hospital onde Hortência trabalhava como enfermeira e acerta com um punhal o peito da irmã, matando-a, depois que ela se recusou a lhe dar dinheiro. A ficção de Marques de Carvalho "copia" a nota policial. No caso real, o irmão também foi ao hospital pedir dinheiro à irmã-amante, que negando, foi morta a facadas. Como na notícia, o assassino não consegue fugir e é imobilizado pela ação heroica de um médico.

\section{Considerações finais}

Neste artigo, vimos que Marques de Carvalho não aderiu de imediato ao Naturalismo e à "literatura do real". Nas primeiras produções literárias, manteve-se fiel ao Romantismo e até se mostrou, em publicações periódicas, avesso à nova estética que no Brasil se aclimatava com sucesso e escândalo. Foi a partir do prefácio de O pajé que o escritor paraense, invertendo a ordem dos fatores, passou a advogar pelo Naturalismo e a censurar o Romantismo, com o mesmo empenho com que fizera o inverso até então. Desse momento em diante, começa a escrever e ambientar os romances na Amazônia paraense, com personagens reais retirados do cotidiano local, seguindo os moldes da nova tendência literária, a exemplo de O pajé e Hortência. Era uma forma de se distinguir de seus comprovincianos e projetar seu nome para o século XX.

Embora não o tenha concluído, O pajé representa a virada de Marques de Carvalho a favor da "escola literária dos documentos humanos". Nesse romance, o escritor paraense aboliu as idealizações românticas e, a partir de um estilo realista e científico, inseriu no enredo cenas que escandalizaram os leitores da época (como o beijo entre Generosa e Mariana), representou grupos sociais até então indignos de retrato literário (como parteiras e pajés) e até personagens célebres e reais da Belém oitocentista, como a tia Faustina, assim como introduziu personagens "baixos" que se deixam corromper pela mentira, pela busca de status social e pelo dinheiro, como o advogado venal Eduardo da Anunciação. 
Em Hortência, Marques de Carvalho apresenta-se de fato como um verdadeiro escritor naturalista, pois não apenas apresenta, de modo a escandalizar e atrair leitores, cenas de sedução e sexo entre irmãos, como também constrói uma narrativa com personagens mestiços pertencentes a grupos sociais marginalizados que vivem tragicamente guiados por instintos e paixões. Como prova de seu compromisso com a "áspera verdade" que se exigia da "literatura moderna", afirma em nota ao final do livro que o romance era baseado em um fato real extraído de uma notícia de jornal.

Marques de Carvalho não foi autor de um único romance supostamente criado a partir de um best-seller naturalista no final do século XIX, como propõem as histórias literárias. Mais do que isso, ele foi o primeiro a escrever na província do Pará romances aos moldes naturalistas, demonstrando domínio das técnicas de escrita e conhecimento dos fundamentos teóricos dessa "literatura do real". Desse modo, graças à virada realista-naturalista, o escritor paraense foi o primeiro a traçar no romance o perfil de uma Belém mulata, obscena, periférica e socialmente marginalizada.

\section{REFERÊNCIAS}

AUERBACH, Erich. Mimesis: a representação da realidade na literatura ocidental. São Paulo: Perspectiva, 1971.

AZEVEDO, Aluísio. O homem. Belo Horizonte-Rio de Janeiro: Garnier, 2003.

BAGULEY. David. Naturalist fiction: the entropic vision. Cambridge: Cambridge University Press, 1990.

BARBOSA, Maurel Ferreira. O pajé: o naturalismo inacabado de Marques de Carvalho (1884-1887). 2011. Dissertação (Mestrado) - Universidade Federal do Pará, Instituto de Filosofia e Ciências Humanas, Programa de Pós-Graduação em História. Belém, 2011.

CARVALHO, Marques de. Hortência. Belém: CEJUP; SECULT, 1997.

MENDES, Leonardo. Rita Baiana: nação e sexualidade em O cortiço. Revista Língua e Literatura, v. 5, n. 8 e 9, p. 21-26, 2003.

MENDES, Leonardo. O aborto, de Figueiredo Pimentel: naturalismo, pedagogia e pornografia no final do século XIX. In: MENDES, Leonardo; CATHARINA, Pedro Paulo (Orgs.). Figueiredo Pimentel: um polígrafo na Belle Époque. São Paulo: Alameda Casa Editorial, 2019. p. 261-349.

MENDES, Leonardo. O romance republicano: naturalismo e alteridade no Brasil, 1880-90. Letras \& Letras, v. 24 , p. $189-207,2008$.

MENDES, Leonardo; GARCIA-CAMELLO, Cleyciara. O homem (1887), de Aluísio Azevedo, como best-seller erótico. ALEA: Estudos Neolatinos (impresso), v. 21, p. 65-80, 2019.

MOREIRA, Eidorfe. O primeiro romance belenense. In: CARVALHO, Marques de. Hortência. Belém: CEJUP; SECULT, 1997. p. 11-18.

SILVA, Alan Victor Flor da; SALES, Germana Maria Araújo. Vozes plurais e dissonantes na imprensa periódica belenense oitocentista sobre a produção literária na província do Pará. RevLet - Revista Virtual de Letras, v. 11, n. 1, p. 279-294, jan/jul, 2019a. 
SILVA, Alan Victor Flor da; SALES, Germana Maria Araújo. Hortência: para além dO homem. In: SILVA, Suellen Cordovil da; SILVA, Alan Victor Flor da; VIDAL, Claudia Valeria França. (orgs.). Literatura e artes da Amazônia paraense: registros e investigações. Porto Alegre: Editora Fi, 2019b.

SIMÕES JUNIOR, Alvaro Santos. Entre Zola e Eça: o Naturalismo brasileiro em seu apogeu (1888). In: Estudos de literatura e imprensa. São Paulo: UNESP, 2014. p. 35-49.

ZOLA, Émile. Do romance: Stendhal, Flaubert e os Goncourt. São Paulo: EDUSP, 1995. 